\title{
ПРИМУС У СЛУЖБОВОМУ ПРАВІ ЯК СИСТЕМНА КАТЕГОРІЯ: ПОНЯТТЯ ТА ХАРАКТЕРИСТИКА ЕЛЕМЕНТІВ
}

Питання застосування примусових заходів традиційно перебуває у полі зору вчених-юристів, в одних випадках при уточненні положень про розуміння сутності примусу як комплексного правового явища та визначенні його специфічних ознак, мети, правомірності та підстав застосування в сучасних умовах, в інших приділяється увага розробці класифікаційних критеріїв їнього розподілу та ефективності застосування в діяльності органів державної влади та місцевого самоврядування, механізму реалізації в окремих галузях права. Проте в наявних як загальнотеоретичних, так і галузевих дослідженнях, які базуються на застосуванні історичного, термінологічного, функціонального, когнітивного аналізу зазначеного правового явища, досить рідко це питання висвітлюється з позиції системного пізнання, що визнати задовільним не можна, оскільки отримання максимально точних висновків про сутність примусу у службовому праві України як інтегративної категорії, розкриття його фактичного призначення, структури, ієрархії компонентів та ефективності їх дії, динаміки подальшого розвитку, можливе лише за умови застосування системного підходу як одного із напрямів методології спеціального наукового пізнання суспільно-правових феноменів, важливість якого неодноразово підкреслювалась у дослідженнях філософів, соціологів, психологів та вчених-юристів.

Сучасному етапу розвитку юридичної науки також притаманне звернення до системного підходу в дослідженні тих чи інших соціально-правових явищ. Так, Л. Заморська, намагаючись охарактеризувати зміст системного підходу як методу сучасних правових досліджень, цілком справедливо акцентує на його універсальності, що призводить не лише до посилення інтересу до змістовної характеристики цього методологічного інструментарію в загальнотеоретичній юридичній науці [1, с. 38-39]: Б. Ганьба застосовує його у дослідженні України як демократичної, соціальної, правової держави [2], В. Єрмоленко - характеризуючи структуру правовідносин [3, с. 11-13], Н. Пархоменко - у дослідженні джерел права [4, с. 60-61], С. Дроботов, В. Ковальський, Т. Радько [5, с. 64; 6, с. 29; 7, с. 24] обгрунто- 
вують доцільність його застосування у дослідженні функцій права, Л. Калєніченко - в аналізі форм державно-правового примусу [8], В. Оболенцев саме системний підхід вважає базовою засадою аналізу держави України [9] тощо), але й актуалізує сучасні галузеві дослідження, в науковій площині яких дедалі частіше він застосовується під час аналізу комплексних правових явищ і процесів, для яких, як і для примусу в службовому праві, характерні динамічність, багатоаспектність, багаторівневість та поліструктурність (так, I. Канзафарова застосовує цей підхід при формуванні теорії цивільно-правової відповідальності (2007р.) [10, с. 101-102]; прикладом використання системного підходу у міжнародному морському праві $є$ праці Є. Передерієва (2007 р.) [11, с. 13-15; 12, с. 143-146], С. Вишновецька як методологічне підгрунтя для аналізу проблем загальної теорії трудового права (2010 р.) [13, с. 29-35], Є. Кірєєва - у вивченні відносин на муніципальній службі (2010р.) [14, с. 7], П. Берназ - задля дослідження криміналістичного забезпечення слідчої діяльності (2015р.) [15, с. 197-202], Ю. Пирожкова - намагаючись здійснити комплексне дослідження теорії функцій адміністративного права (2016 р.) [16, с. 181-182], І. Болокан розробляючи теорію реалізації норм адміністративного права (2017р.) [17, с. 171] тощо.

У процесі моделювання система примусових заходів у службовому праві як об'єкт наукового дослідження не є винятком, варто враховувати всі наявні закономірності загальної теорії систем, адже ми цілком поділяємо позицію В. Садовського, що теоретично будь-який об'єкт наукового дослідження можна розглянути як систему $[18$, с. 12]. У цьому контексті треба зазначити, що аналіз наукової літератури дає змогу сформулювати висновок, що поняття «система» $є$ загальнонауковим та міждисциплінарним, внаслідок чого $є$ нині одним із ключових під час вивчення та конструювання соціальних, інформаційних і технічних складних систем, одним із головних методологічних засобів пізнання суспільних, природничих i технічних наук, таких як біологія, інформатика, математика, медицина, кібернетика, економіка, психологія, соціологія, педагогіка, філософія та ін., а також активно застосовується в юриспруденції. Відповідно, варто підтримати І. Болокан та Ю. Пирожкову, які, враховуючи відсутність єдиного загального алгоритму конструювання та дослідження системи, пропонують методику іiі побудови та висвітлення (вказані автори - стосовно реалізації адміністративно-правових норм та функцій адміністративного права) таким чином: 1) з'ясування визначення поняття «система», його співвідношення із суміжними поняттями - структура, системологія та систематика; 2) встановлення універсальних системних параметрів - окреслення однорідних та специфічних властивостей елементів зазначеної системи; 3) дослідження загальносистемних властивостей елементів системи та визначення закономірностей їх внутрішньо системного взаємовпливу та зовнішніх зв'язків. Крім цього, І. Болокан цілком слушно зауважує, що доцільно враховувати теоретичні положення, пов'язані з використанням системного підходу як методологічної основи наукових досліджень у галузі 
права, серед яких системно-компонентний, системно-структурний, системно-функціональний, системно-інтеграційний, системно-комунікаційний та системно-історичний аспекти [16, с. 181-182; 17, с. 171].

Не занурюючись у деталізацію тлумачення поняття «система» у довідковій, словниково-енциклопедичній та науковій, у тому числі фаховій, літературі, оскільки ці питання розглядаються у численних фундаментальних, у тому числі і галузевих правових дослідженнях (варто виділити роботи А. Авер'янова, І. Болокан, Н. Вітрук, Т. Коломоєць, О. Кваши, Р. Мельника, В. Могилевського, Н. Полевого, М. Рассолова, М. Сатуріна, Ю. Пирожкової, Т. Радька). Як зазначають автори навчального посібника «Вступ до системного аналізу» (2004р.), зустрічається понад сорок різнопланових визначень цього поняття (зауважимо, що зазначений висновок належить В. Садовському, який ще у 1974 р. за результатами проведеного аналізу встановив використання сорока найбільш поширених іiі визначень [19, с. 93-99], а В. Томашевський у підручнику «Моделювання систем» (2005р.) [20] зазначає, що нині є понад 500 визначень цього терміну), у зв'язку з чим у сучасній філософії, теоретичних та прикладних науках не можуть підібрати однозначного трактування змісту цього поняття, оскільки донині залишається відкритим питання, що саме $€$ «ядром» системи, іiі стрижнем.

Отже, розглянемо під критичним кутом зору основні пропозиції, які у вищезгаданому навчальному посібнику пропонується залежно від підходу поділити на три групи $[21$, с. 11$]$ :

1) визначення системи через поняття системного підходу - «елементи», «відносини», «зв'язки», «иіле», «иілісність», при чому категорія «система» означає цілісну сукупність взаємопов'язаних частин. Зазначений підхід будується на досить широкому спектрі тлумачення терміна «система», який походить від давньогрецького би́отина та означає «сполучення, організм, будова, організація, устрій». Типовим прикладом може бути позиція I. Дудніка, який вважає, що система $є$ відмежованою від зовнішнього середовища сукупністю взаємопов'язаних частин (компонентів), вона володіє якісно вищими та складнішими властивостями порівняно із сумою властивостей іï частин і характеризується певним складом (набором) компонентів і певним способом їх взаємодіï [23], при чому розпочинається лише там, де ці компоненти утворюють певну цілісність, $€$ взаємозалежними та виконують лише притаманну ним функцію. Аналізуючи наведені визначення, цілком прийнятним вважаємо зауваження В. Оболенцева, висловлене у монографічному дослідженні «Базові засади системного аналізу держави України» (2018р.) щодо можливості, проте недосконалості такого розуміння досліджуваного поняття: цілком справедливо вчений наголошує на тому, що «сукупності бувають кінцеві та нескінченні, впорядковані та невпорядковані тощо» [9, с. 9];

2) визначення системи з позииї теорії регулювання через поняття «вхід», «вихід», «переробка інформації», «закон поведінки», «керування». Так, скажімо, у навчальному посібнику з моделювання аеронавігаці- 
йних систем, обробки інформації та прийняття рішень у системі керування транспортних рухом В. Васильєв, В. Харченко розглядають систему керування транспортним рухом як безперервний, надійний та оперативний процес регулювання, який складається зі збору, обробки, аналізу, відображення інформації, формування рішень та передавання команд керування [24, с. 14]. Продовжуючи, зазначимо, що така кібернетична трактовка системи є, на нашу думку, досить обмеженою, оскільки «захоплення» однією ознакою системи, іï керованістю (урегульованістю, підпорядкованістю, прогнозованістю) призводить до того, що поза увагою дослідників залишаються всі інші суттєві властивості зазначеного поняття, серед яких складна ієрархічна організація, здатність до саморегуляції, мета, на яку «націлені» всі елементи системи та їх взаємозв'язок;

3) у третій групі поняття «системи» визначається як деякий клас математичних моделей через доведення певних математичних співвідношень, які описують досліджуваний процес або явище. Саме такий підхід до досліджуваного поняття створив підгрунтя для прикладних наукових досліджень у різноманітних галузях знань (А. Горячко і Т. Горячко на підставі математичного моделювання досліджують серце як провідну систему організму людини [25, с. 60-65], В. Поліщук - у дослідженні ефективності відновлення автомобільної і спеціальної техніки [26, с. 93-96]; Б. Корнієнко і Л. Галата - у вивченні системи інформаційної безпеки [27, с. 114-118] тощо). Отже, вказаний підхід базується на розумінні системи як відношення.

Намагаючись здійснити системний аналіз об'єктів та процесів комп'ютерізації, А. Катренко виділяє дві групи визначень системи [28], зазначаючи, що до першої групи належать визначення, які не виділяють поняття цілісності системи, а інтерпретують ії з позиції теорії множини сукупності певних елементів, об’єктів. При чому варто зауважити, що у науковому обігу, досліджуючи цілісність як базову ознаку системи, вчені виокремлюють та порівнюють два типи систем. Це, по-перше, системи чітко відмежовані від середовища, наявність яких не потребує доведення, оскільки навіть на початку дослідження ці системи мають вигляд цілісного об'єкта, якому притаманна множина проявів (живі істоти, об'єкти природи) та, на відміну від штучних об’єктів, створених людьми, категорія цілепокладання для них не є обов'язковою, адже незалежно від неї не змінює результат ix функціонування. По-друге, є системи (і примус у службовому праві належить саме до цієї категорії), які потребують моделювання на підставі дослідження базових структурних системних елементів. Тому, висловлюючись із приводу наведеної позиції, зазначимо, що вважаємо за доцільне підтримати саме ті дослідження системи, які розуміють іï через сукупність елементів, які утворюють єдине ціле.

3 огляду на наведене під системою «примус у службовому праві» варто розуміти комплексну підсистему адміністративного примусу, упорядковані, взаємопов'язані та взаємодіючі інтегративні елементи (примусові заходи) якої утворюють єдине ціле, спрямовані на досягнення стратегічної мети - забезпечення стабільності функціонування публічної служби та 
застосовуються у зв'язку з публічною, постійною, професійною діяльністю осіб, які обіймають посади у публічних інституціях.

Наступним необхідним етапом пізнання досліджуваного питання є узагальнення наукових підходів до примусу як системної правової категорії. Саме такий підхід дасть змогу врахувати всі важливі параметри не лише для моделювання системи примусу у службовому праві України та з'ясування його сутності як цілісного правового інституту, встановити межі його застосування, але й створить підгрунтя для якісної подальшої розробки та дослідження потенціалу всіх його структурних елементів (примусових заходів), що сприятиме розв'язанню не лише теоретичних проблем, серед яких досить часто простежується ототожнення понять «примус як системна правова категорія» та «класифікація примусових заходів» (дослідження І. Демідова, О. Красавчикова, Л. Калєніченко, А. Талюпи, Н. Маленіна, А. Чашнікова та ін.), при чому таке поверхове ставлення до характеристики примусу як системної категорії спостерігається навіть на рівні дисертаційних робіт, до яких належать дослідження Д. Ісаєва «Система заходів примусу та порядок їх застосування у кримінальному процесі Росіі» (2009 р.) [29], Д. Коваль «Система заходів процесуального примусу у фінансовому праві» (2011р.) [30, с. 9] тощо, сприятиме удосконаленню чинного законодавства у зазначеній сфері суспільних відносин, підвищенню ефективності реалізації примусових заходів у службовому праві України та оптимізації механізму його застосування, забезпечить захист прав і свобод публічних службовців під час використання його ресурсу.

Враховуючи визначену нами мету системного аналізу примусу у службовому праві як динамічної цілісності, що складається із взаємопов'язаних елементів, використовуючи напрацьовані у доктрині права положення до системного підходу, необхідними складниками якого $є$ компонентний, структурно-функціональний, історичний та інтегративний аспекти, оберемо як базовий (хоча й інші підходи, безперечно, є цікавими та можуть становити предмет подальших досліджень цього питання) системно-структурний підхід, оскільки саме він дасть змогу охарактеризувати внутрішні зв'язки елементів системи, а також ї взаємодію, охарактеризувати примус у службовому праві як системну категорію 3 унікальними якісними особливостями та окреслити взаємозв'язок його структурних елементів із системою адміністративного примусу. 3 огляду на зазначене, на інтеграційність, комплексність та мету примусових заходів у службовому праві, обгрунтовано вести мову про моделювання ї системи, умовно виділивши у ній:

1 блок - ЗАХОДИ ПОПЕРЕДЖУВАЛЬНОГО ВПЛИВУ (застосування яких не пов'язане із протиправними діяннями): а) заходи попереджувального впливу, які застосовуються із загальнопревентивною метою; б) заходи попереджувального впливу, які застосовуються зі спеціально превентивною метою; в) заходи припинення.

ІІ блОК - ЗАХОДИ ПРИМУСУ, ПОВ'ЯЗАНІ З ЮРИДИЧНОЮ ВІДПОВІДАЛЬНІСТЮ: а) адміністративні стягнення; б) дисциплінарні стягнення. 
Моделюючи та досліджуючи систему примусових заходів у службовому праві, варто зазначити, що вона $є$ відкритою та динамічною, що дає змогу припустити можливість іï модифікації у разі трансформації базових засад службового права. Так, наприклад, узгодження національного законодавства 3 визнаними європейськими стандартами, його гармонізація з нормами міжнародного права, запозичення позитивного досвіду щодо організаційних, правових і політичних інструментів задля протидії корупції зумовили в межах вітчизняного службового права появу інноваційного інструменту боротьби із цим латентним, системним, негативним соціальним явищем - запровадження антикорупційного декларування доходів осіб, уповноважених на виконання функцій держави або місцевого самоврядування. Зазначене відразу ж вплинуло на досліджувану нами систему, оскільки суттєво розширило коло запобіжних превентивних антикорупційних заходів (із метою попередження корупційних правопорушень антикорупційному декларуванню відповідно до ст. 1 Закону України від 14.10.2014 p. «Про запобігання корупції» підлягають не лише особи, уповноважені на виконання функцій держави або місцевого самоврядування, юридичні особи публічного права, але й особи, які претендують на вступ до публічної служби). Окрім того, посилено відповідальність декларантів, що свідчить про трансформацію другого блоку примусових заходів досліджуваної системи.

Таким чином, підбиваючи підсумки, варто зазначити, що примусові заходи у службовому праві не існують відокремлено, між ними $€$ постійний взаємозв'язок, адже жоден із них, навіть той, який на певному етапі розвитку службового права домінує, не здатен самостійно реалізувати його ресурс, що і створює вагомі підстави для наукового використання та подальшого дослідження поняття примусу у службовому праві як системної категорії. Як і будь-якій системі, їй притаманні основні властивості структурність (наявність елементів - окремих примусових заходів) та обов'язкова наявність зв'язків між ними, що забезпечують інтегративність (єдність, цілісність) цієї системи. Структура зазначеної системи включає два взаємопов'язаних блоки, що існують лише у сукупності: перший блок заходи попереджувального впливу, для яких характерні такі властивості (комплексність та взаємозумовленість; урегульованість нормами службового права; чітка превентивна спрямованість; загальна мета - недопущення вчинення правопорушення у сфері публічної служби) та які посідають основоположне, центральне місце в системі примусових заходів службового права. До другого блоку системи належать заходи примусу, пов'язані з юридичною відповідальністю, метою яких є покарання особи, яка вчинила правопорушення у службових правовідносинах.

\section{Література}

1. Заморська Л.І. Системний підхід у дослідженнях правової реальності. Вісник Південного регіонального центру Національної академії правових наук України. 2016. № 7. С. 38-44.

2. Ганьба Б.П. Системний підхід та його застосування в дослідженні України як демократичної, соціальної, правової держави: автореф. дис. .... канд. юрид. наук: 12.00.01. Харків, 2001. 19 с. 
3. Єрмоленко В. Об’єкт у структурі правовідносин. Юридична Україна. 2004. № 1. C. $11-15$.

4. Пархоменко П.М. Системність як істотна ознака джерел права і Правова держава. К.: Ін-т держави і права ім. В.М. Корецького НАН України, 2007. Вип. 18. С. 59-68.

5. Дроботов С.А. Реалізація функцій права в умовах розвитку демократичної, правової держави: дис. ... канд. юрид. наук: 12.00.01. Відкритий міжнар. ун-т розвитку людини «Україна». Київ, 2011. 219 с.

6. Ковальський В.С. Охоронна функція права: монографія. Київ: Юрінком Інтер, 2010. 336 c.

7. Радько Т.Н. Теория функций права: монографія. Москва: Проспект, 2014. 272 с.

8. Калєніченко Л. Система форм державно-правового примусу Jurnalul juridic national: teorie şi practică = Национальный юридический журнал: теория и практика. 2018. № 1, T. 1 (Februarie). C. 10-14.

9. Оболенцев В.Ф. Базові засади системного аналізу системи держави України: монографія. Харків: Право, 2018. 98 с.

10. Канзафарова I.C. Теоретичні основи цивільно-правової відповідальності: монографія. Одеса: Астропринт, 2006. 264 с.

11. Передерієв Є. Система права як фундаментальна категорія структурних понятійних рядів міжнародних морських правовідносин. Підприємництво, господарство і право. 2007. № 3. С. $13-15$

12. Передерієв Є. Вплив глобальної юридичної системи на міжнародні морські правовідносини. Право України. 2007. № 3. С. 143-146.

13. Вишновецька С.В. Системний підхід у дослідженні методологічних проблем загальної теорії трудового права: постановка проблеми. Актуальні проблеми держави і права: збірник наукових праць. Вип. 52. Одеса: Юридична література, 2010. 476 с.

14. Киреева Е.А. Муниципальная служба в условиях реформы государственного управления: вопросы методологии и практики: автореф. дис. ... д-ра юрид. наук: 12.00.02. Москва, 2010. $54 \mathrm{c}$.

15. Берназ П.В. Системний підхід як методологічне підгрунтя дослідження криміналістичного забезпечення слідчої діяльності. Південноукраїнський правничий часопис. 2015. № 2 . C. 197-202.

16. Пирожкова Ю.В. Функції адміністративного права: генеза, теоретичний, нормативний та праксеологічний аспекти: монографія. Запоріжжя: Видавничий дім «Гельветика», 2016. 548 с.

17. Болокан I.В. Теорія реалізації норм адміністративного права: монографія. Запоріжжя: Видавничий дім «Гельветика», 2017. 560 с.

18. Садовский В.Н. Исследования по общей теории систем / общ. ред. Э.Г. Юдина. Москва: Прогресс, 1969. 520 с.

19. Садовский В.Н. Основания общей теории систем. Логико-методологический анализ. Москва: Наука, 1974. 280 с.

20. Томашевський В.М. Моделювання систем. Київ:Вид. групи ВНV, 2005. 352 с.

21. Коваленко І.І., Бідюк П.І., Гожий О.П. Вступ до системного аналізу: Навчальний посібник. Миколаїв: МДГУ ім. Петра Могили, 2004. 148 с.

22. Сучасний словник іншомовних слів: походження слів, розгорнуті пояснення, слова синоніми / Укл. Н.І. Нечволод-Харків Торсінг плюс, 2007. 768 с.

23. Дудник I.M. Вступ до загальної теорії систем. URL: http://www.dut.edu.ua/ uploads/1_1142_42884991.pdf

24. Моделювання аеронавігаційних систем. Оброблення інформації та прийняття рішень в системі керування повітряним рухом: навч. посіб. / В.М. Васильєв, В.П. Харченко. К.: НАУ, 2008. $180 \mathrm{c}$.

25. Горячко В. Математична модель провідної системи серця людини. Теоретична електроніка. 2007. С. 60-65.

26. Поліщук В.В. Математична модель функціонування системи відновлення автомобільної спеціальної техніки військового призначення Modern Information Technologies in the Sphere of Security and Defence. 2015. № 3 (24). C. 93-96.

27. Корнієнко Б., Галата Л. Розробка і дослідження математичної моделі системи інформаційної безпеки в комп’ютерній мережі. Наукоємні технології, 2017. Том 34, № 2. С. 114-118. 
28. Катренко А.В. Системний аналіз об’єктів та процесів комп’ютерізації. Львів: «Новий світ - 2000», 2003. 424 с.

29. Исаев Д.Р. Система мер принуждения и порядок их применения в уголовном процессе. URL: http:/ / www.dissercat.com/content/sistema-mer-prinuzhdeniya-i-poryadok-ikh-primeneniyav-ugolovnom-protsesse-rossii

30. Коваль Д.О. Система заходів процесуального примусу у фінансовому праві: автореф. дис ... канд. юрид. наук: 12.00.07. Київ, 2011. 19 с.

\section{А н о т а ці я}

Припутень Д. С. Примус у службовому праві як системна категорія: поняття та характеристика елементів. - Стаття.

Системний підхід є універсальним, сприяє формуванню відповідного адекватного формулювання суті досліджуваних проблем у конкретних науках і вибору ефективних шляхів їх вирішення. У статті приділено увагу грунтовному аналізу примусу у службовому праві як єдиному цілому з узгодженим функціонуванням закономірно розташованих і взаємопов'язаних елементів і частин, що дало змогу не лише окреслити перелік примусових заходів, але й відстежити модифікацію їх елементів у взаємозв'язку. У проведеному дослідженні наводиться авторське визначення та змодельовано систему примусу у службовому праві.

Ключові слова: система, системні дослідження, примус, примус у службовому праві, попередження, заходи відповідальності.

\section{Ан нота ция}

Припутень Д. С. Принуждение в служебном праве как системная категория: понятие и характеристика элементов. - Статья.

Системный подход является универсальным, способствует формированию соответствующего адекватного формулировка сути исследуемых проблем в конкретных науках и выбора эффективных путей их решения. В статье уделено внимание обстоятельному анализу принуждения в служебном праве как едином целом с согласованным функционированием закономерно расположенных и взаимосвязанных элементов и частей, что позволило не только определить перечень мер принуждения, но и отследить модификацию их элементов во взаимосвязи. В проведенном исследовании приводится авторское определение и смоделирована система принуждения в служебном праве.

Ключевые слова: система, системные исследования, принуждение, принуждение в служебном праве, предупреждение, меры ответственности.

\section{S u m m a r y}

Pryputen D. S. Compulsion in the service law as a system category: the concept and characteristics of the elements. - Article.

The system approach is universal, contributes to the formation of appropriate adequate formulation of the essence of the problems studied in specific sciences and the choice of effective ways to solve them. The article focuses on a thorough analysis of coercion in the service law as a whole with the co-ordinated functioning of legally located and interconnected elements and parts, which allowed not only to outline the list of compulsory measures, but also to track the modification of their elements in the relationship. As a result of the research, the author's definition is given and the system of coercion in the service law is modeled.

Key words: system, systematic research, coercion, compulsion in the service law, prevention, measures of responsibility. 